\title{
THE RELATIONSHIP BETWEEN GEODIVERSITY AND HABITAT RICHNESS IN ŠUMAVA NATIONAL PARK AND KŘIVOKLÁTSKO PLA (CZECH REPUBLIC): A QUANTITATIVE ANALYSIS APPROACH
}

\author{
KATEŘINA JAČKOVÁ, DUŠAN ROMPORTL \\ Department of Physical Geography and Geoecology, Faculty of Science, Charles \\ University, Albertov 6, 12843 Prague 2; jackova@natur.cuni.cz
}

Received: $21^{\text {st }}$ April 2008, Accepted: $31^{\text {st }}$ October 2008

\begin{abstract}
This paper focuses on the development of a quantitative method for evaluating the relationship between abiotic heterogeneity and habitat richness at the landscape level. The study took place in the Křivoklátsko protected landscape area and Šumava national park (Czech Republic). Our initial hypothesis was that habitat richness should be high in areas with high abiotic heterogeneity, and vice versa. GIS vector layers of habitat were used for the formulation of habitat richness. A geological layer, a digital terrain model and hydrographic layers were used to determine abiotic heterogeneity. The study areas were overlain by a grid square and habitat richness and abiotic heterogeneity were assessed in each study cell. The data obtained were used in a statistical model (multiple spatial linear regression, with maximum credibility). The results of the statistical model indicated a significant influence of abiotic heterogeneity on habitat richness.

Key words: geodiversity, abiotic heterogeneity, habitat richness, Šumava NP, Křivoklátsko PLA, GIS, multiple spatial linear regression, landscape level, NATURA 2000
\end{abstract}

\section{INTRODUCTION}

The relationship between biotic and abiotic components of nature has long been part of the traditional scope of natural science research. This study focuses on an evaluation of the relationship between biodiversity and geodiversity, a relationship that has been the subject of several previous studies (e.g. see Burnett et al., 1998; Nichols et al., 1998; Davidar et al., 2007). This important topic, however, is still relatively marginal and, especially in the Czech Republic, has been studied using mainly qualitative methods and at a local level. Recent progress in the use of geographical information systems (GIS) and statistical software provides an opportunity to look at the landscape from a new perspective, with new connections and at new scales. For this reason, the development and verification of quantitative methods are both useful and highly recommended.

The term biodiversity is generally well known. Current research and nature conservation practice strongly emphasize the need for monitoring, understanding and protecting biodiversity (Gray, 2004; Ložek, 2005). Despite many of the disturbances affecting plants and animals being largely the consequence of abiotic environmental degradation, however, biodiversity protection has not always been undertaken in context with abiotic conditions (Ložek, 2000; Sharples, 2002). 
The term geodiversity is less well known. Its origin can be dated to the beginning of the 1990s, when it first appeared in a study on geoconservation from Tasmania (Gray, 2004). The most exact definition of geodiversity also comes from Australia: "the natural range (diversity) of geological, geomorphological and soil features, assemblages, systems and processes. Geodiversity includes evidence of the past life, ecosystems and environments in the history of the earth as well as a range of atmospheric, hydrological and biological processes currently acting on rocks, landforms and soils" (Australian Natural Heritage Charter, 2002). In the context of abiotic nature, geodiversity can be seen as a parallel to biodiversity.

Unlike biodiversity evaluation, standardized methods for evaluating geodiversity have yet to be established. According to Johansson (2000) (in Gray, 2004), geodiversity can be described as the "diversity of geological and geomorphological features in a study area". Geodiversity evaluation, however, must also include the interpretation of processes and relationships among its components (Gray, 2004). Vincent (in Prosser, 2002) emphasized the need to measure geodiversity using an index based on a grid square overlying the study area, thus allowing the comparison of values for geodiversity in different cells of the grid. Silva (2004) suggested the use of geodiversity indices to evaluate the relationship with biodiversity, the indices being based on the sum of the classes of features observed resulting from landforms in landscape units (e.g. elevation, slope, land use). Similarly, Burnett et al. (1998) used an index of geomorphological heterogeneity that was based on soil features and a digital terrain model. According to Kot et al. (2006), however, it is not possible to propose a universal geodiversity index; it is preferable to consider a set of suitable indicators or the relations among them in addition.

As geodiversity can have a strong impact on biodiversity (Cílek, 2002; Burnett et al., 1998; Gordon et al., 2006; Gray, 2004; Kozlowski, 2004; Kučera, 1999; Ložek, 2000; Pemberton, 2002; Spehn et al., 2003; Stanley, 2003), it is vital that the relationships between geodiversity and biodiversity are correctly understood in order to provide efficient landscape management and protection, particularly when using an ecosystem approach (Gordon et al., 2006; Ložek, 2005; Nichols, et al., 1998; Sharples, 2002 in Gray, 2004).

The aim of this study, therefore, was to develop a quantitative methodology for the evaluation of relationships between habitat biodiversity and abiotic heterogeneity at the landscape level and to statistically determine the most significant abiotic features. Measurement of biodiversity at the landscape level is very difficult, however, and data are not generally available (Costanza, 2007). Habitat richness data from NATURA 2000 mapping was used, therefore, as a proxy (admittedly imperfect) for habitat biodiversity.

According to our initial hypothesis, habitat richness should be high in areas with high abiotic heterogeneity, and vice versa. The proposed methodology might also be applied as a base for geodiversity evaluation on its own.

\section{METHODOLOGY}

\section{Study areas}

The study took place in the Křivoklátsko Protected Landscape Area (PLA) and Šumava National Park (NP). Due to their histories, these study areas have had less anthropogenic impact in comparison with the rest of the Czech Republic and, therefore, retain a high degree of relative "naturalness". The Krrivoklátsko PLA was almost devoid of inhabitants during prehistoric times and it became a favoured hunting ground of the Czech nobility in 
the Middle Ages, which ensured its protection from agricultural expansion. Šumava NP was covered by virgin primeval forest up to the $18^{\text {th }}$ century. Later colonisation had an important impact, resulting in creation of the present wooded and non-wooded ecosystems. Sumava NP formed part of the "Iron Curtain" following the Second World War and, hence, was subject to low anthropogenic impact.

The Krrivoklátsko PLA covers an area of $628 \mathrm{~km}^{2}$ and is situated in the centre of Bohemia (Fig. 1). The relief is hilly and rugged and the whole area is divided by the River Berounka.

Fig. 1: Localisation of the study areas

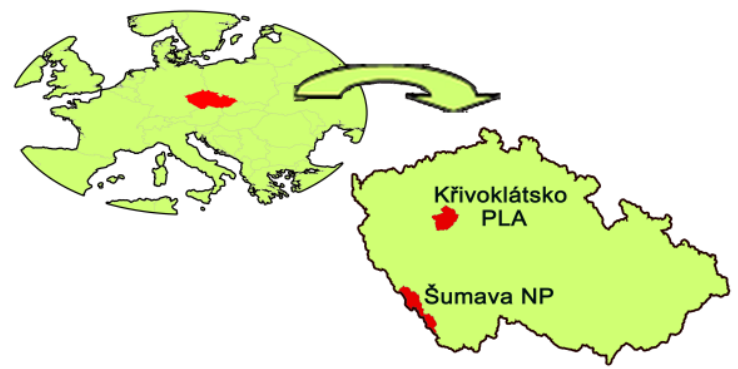

Elevations range between 223 and 616 metres above sea level (Fig. 2). The average superelevation approaches $100 \mathrm{~m}$, and even $250 \mathrm{~m}$ in the Berounka river valley. Steep slopes and rocks in the river valleys represent important refuges for plant and animal populations. More than $2 / 3$ of the area is covered by broadleaved and mixed forests. The climate is middle warm (average annual temperature $7-8^{\circ} \mathrm{C}$ ) and drier (precipitation 500 $550 \mathrm{~mm} /$ year), though the mesoclimate is highly influenced by relief (i.e. temperature inversion). The geological substrate is very rich (Kolbek et al., 1997).

Fig. 2: The Křivoklátsko Protected Landscape Area study site

Source: COSMC (2006)

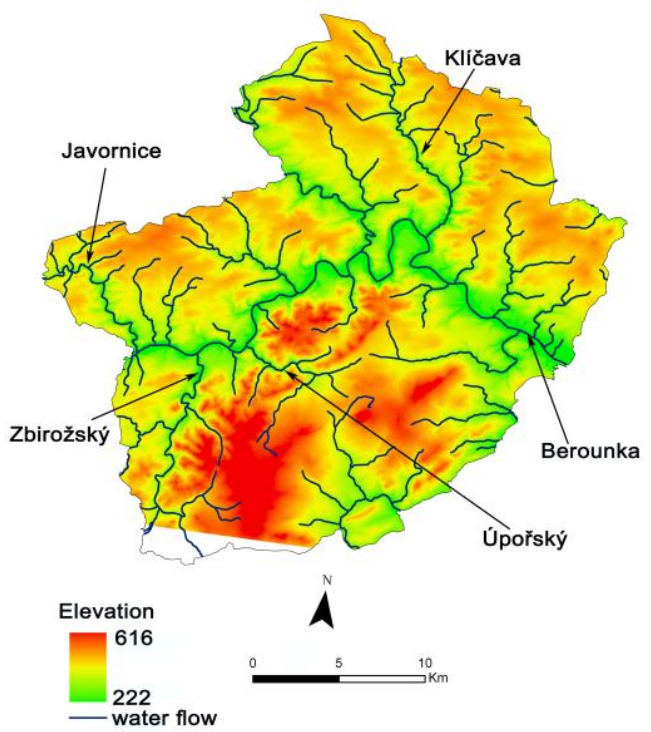


Šumava NP lies in southern Bohemia (Fig. 1) and covers over $680 \mathrm{~km}^{2}$. It consists of a forested range of mountains of rounded form with vast upland plateaux. Peaks and eroded stream valleys (e.g. Vydra, Křemelná) have developed in the central part of the plateaux. The main watercourses are the rivers Vltava and Otava.

The geological substrate is mainly poor. The elevation ranges between 563 and 1,375 m.a.s.l. (Fig. 3). The climate depends on elevation and ranges between mild humid in lower areas up to cold and rich in precipitation in the upland plateaux. Annual precipitation is 800 to $1,600 \mathrm{~mm} /$ year and the average temperature is 3.5 to $6.5^{\circ} \mathrm{C}$. Šmava NP is typified by a large number of spring areas and wetlands (Administration of the Šumava NP, 2006).

\section{Fig . 3: The Šumava National Park Study site}

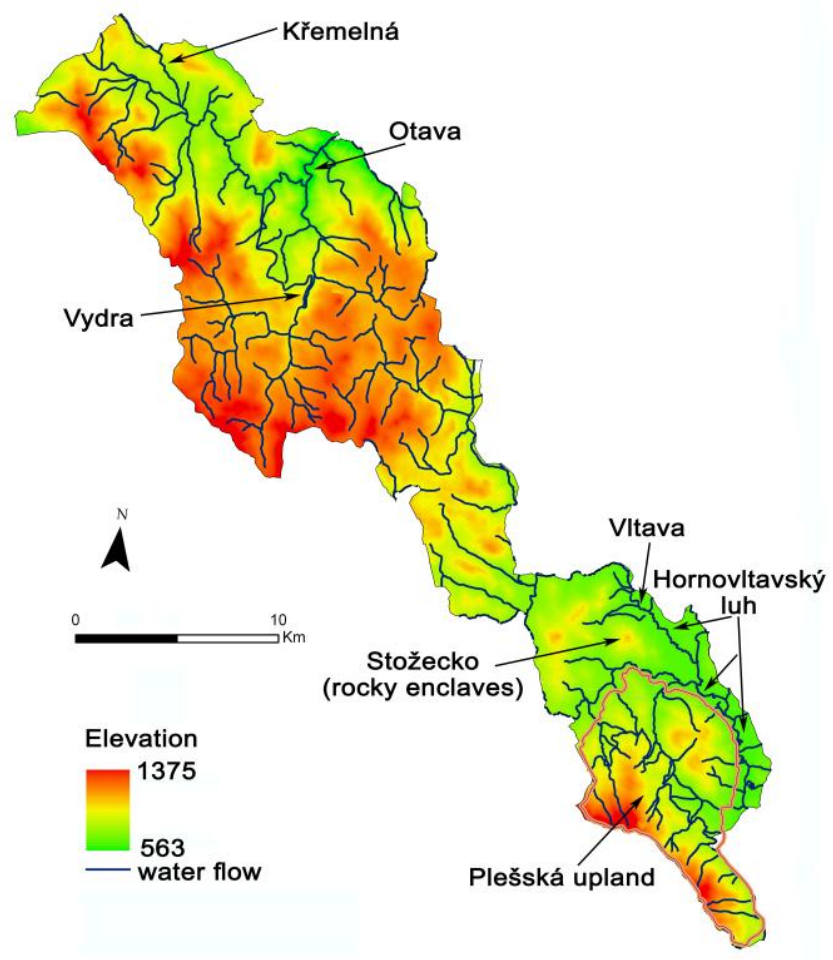

Source: COSMC (2006)

\section{Data}

The recording of habitat abundance during mapping for NATURA 2000 provided a unique dataset for the Czech Republic. The GIS vector layer of habitats (ANCPL CR, 2006) was used for the formulation of habitat richness. The data set was based on a scale of $1: 10,000$ and the minimum mapping unit was $2,500 \mathrm{~m}^{2}$. One mapping unit can include several small biotopes with a minimum area of $25 \mathrm{~m}^{2}$, these units being termed mosaics (Guth, 2002). In this context, habitat refers to a typological mapping unit according to the Habitat catalogue of the Czech Republic (Chytrý et al., 2001). For the purposes of this study, the typological units were generalised to a level of basic sub-units and only areas 
with natural biotopes were analysed (or mosaics including natural biotopes). The structure and range of habitat mapping for NATURA 2000 in the study areas are shown in Table 1.

Table 1: Range and structure of habitat mapping in Křivoklátsko Protected Landscape Area and Šumava National Park

\begin{tabular}{|c|c|c|c|c|}
\hline \multirow[b]{2}{*}{ Habitat mapping type } & \multicolumn{2}{|c|}{ Šumava NP } & \multicolumn{2}{|c|}{ Křrivoklátsko PLA } \\
\hline & Area $\left(\mathrm{km}^{2}\right)$ & $\%$ & Area $\left(\mathrm{km}^{2}\right)$ & $\%$ \\
\hline Natural habitat & 420.35 & 61.8 & 172.45 & 27.5 \\
\hline $\begin{array}{l}\text { Mosaic, including natural and } \\
\text { non-natural habitats }\end{array}$ & 147.58 & 21.7 & 43.60 & 6.9 \\
\hline Total area & 680.64 & 100 & 627.92 & 100 \\
\hline
\end{tabular}

Source: ANCLP CR (2006)

The heterogeneity of abiotic conditions was formulated using the following GIS digital layers: the geological map from the GEOČR 50 database (CGS, 2006), with a scale of 1:50,000; and the digital terrain model derived from the ZABAGED database (COSMC, 2006), with a $10 \mathrm{~m}$ resolution and including the hydrographical layers for water flows, water surfaces, shorelines and moss/swamp areas from the ZABAGED database (COSMC, 2006), at a scale of 1:10,000.

Only those parts of the study areas previously mapped as having natural biotopes were involved in the evaluation, these areas having relatively low anthropogenic influence. Anthropogenic influence is, however, assumed to be the dominant impact on habitat richness. The use of historic and current land-use data in the analysis would definitely improve the statistical model. The quantification of such data, however, is problematic. For this reason, anthropogenic influence remains an unexplained variable in the model as regards habitat richness. We would expect a lower ratio, therefore, for the explained habitat richness variability.

\section{Methodical procedure}

The initial digital layers were processed using the ArcInfo 9.2 and Workstation 9.2 software packages (ESRI, 2006), and Matlab R2006A software (The Math Works, 2006) was used for the various substeps. The R 2.5.0 software (Free Software Foundation, 2007) and its extensions for spatial data "sp" (Pebesma et al., 2007) and for geostatistical analysis "GeoR" (Ribeiro et al., 2007) were used for statistical modelling.

The study areas were overlaid with a grid square and values were further determined for natural conditions within each cell of the grid. Due to the fragmented cover of natural biotopes, only those cells with a minimum of $95 \%$ of their areas mapped with natural biotopes were analysed. The $95 \%$ threshold provides a negligible non-mapped area and, at the same time, enables a greater number of grid cells to be analysed.

It is essential that the appropriate scale be used for the analysis of landscape processes, patterns and relations (Gustafson, 1998) and, therefore, it is crucial that the cell size of the grid square be appropriate to the phenomenon examined. The definition of cell size, however, involves a number of methodological problems and the question of an "ideal" cell size remains, to a certain extent, open. In this study, we defined the cell size as 9 hectares. This cell size guarantees that we interpret the natural conditions to the best level possible 
and, at the same time, provides enough data for statistical modelling. Though a larger cell size would have been more appropriate in the case of Šmava NP due to the larger spatial scales involved, it was decided to use a uniform cell size in order to ensure comparability of the data sets for both study areas.

In the Krrivoklátsko PLA, 312 cells were analysed (Fig. 4), these being distributed unevenly over the whole area, and totally absent from the northwestern part of the PLA. In Šmava NP, 2,963 study cells were analysed (Fig. 4) and covered most areas of the park.

Fig. 4: Study cells in Křivoklátsko Protected Landscape Area and Šumava National Park

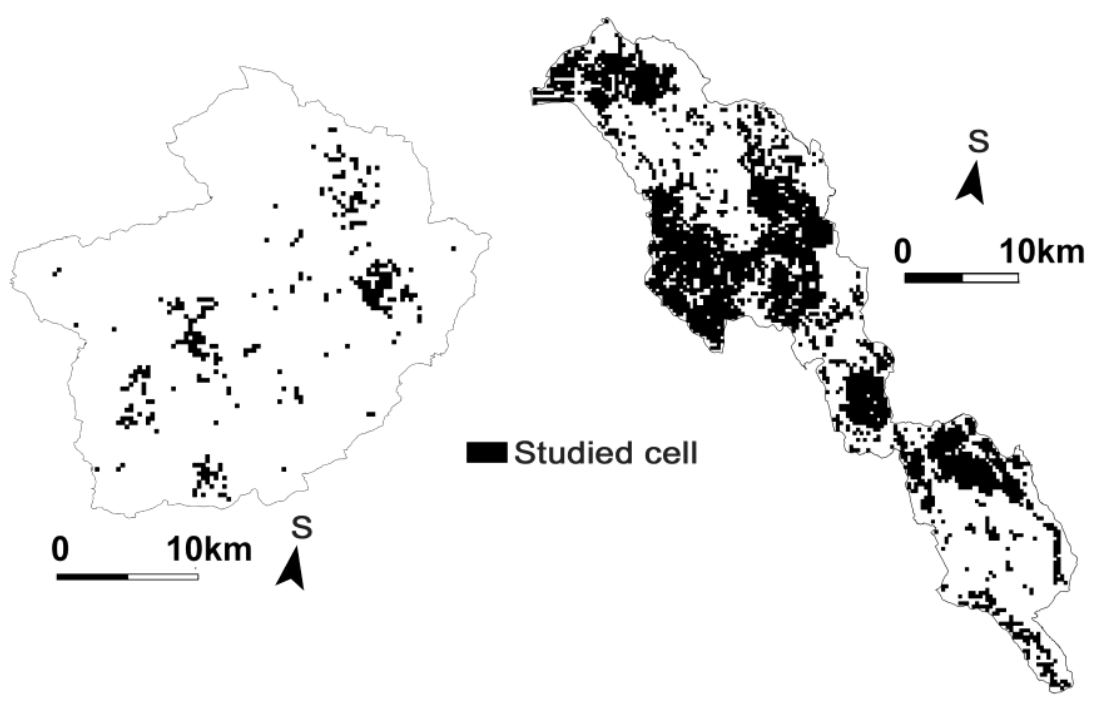

Source: ANCLP CR (2006)

The square grid was constructed using a freeware toolset, Hawth's Analysis Tools for ArcGis (Beyer, 2004). Habitat richness and the predefined abiotic features (chosen based on a literature search and knowledge of the study areas, and which sufficiently express, in an indirect manner, the heterogeneity of abiotic conditions (such as insolation, mesoclimate and topography) were assessed for each study cell (see Table 2 for an overview of the variables assessed). An increased number of alternatives were provided for the formulation of some abiotic conditions. This enabled the most suitable method for defining the variable to be chosen for the study areas based on a gradual inclusion into the statistical model and comparison of their output parameters. Spatial linear regression (maximum credibility method) was used to determine the most significant abiotic heterogeneities (independent variables) and the level of correlation with variability in habitat richness (dependent variable). The final model was chosen based on the value of the Bayesian information criterion. The statistical model, as well as the methodological procedure, is described in detail in Jačková (2007). 
Table 2: Definition of variables (habitat richness and heterogeneity of abiotic conditions)

\begin{tabular}{|c|c|c|c|}
\hline Initial layer & Secondary layer & Determination of diversity & Variable \\
\hline Habitat layer & Natural habitat layer & $\begin{array}{l}\text { Number of typological units in } \\
\text { a studied cell }\end{array}$ & Habitat richness \\
\hline $\begin{array}{l}\text { Geological } \\
\text { map }\end{array}$ & $\begin{array}{l}\text { Map of rock types consolidated } \\
\text { in } 15 \text { categories }\end{array}$ & $\begin{array}{l}\text { Number of typological units in } \\
\text { a studied cell }\end{array}$ & $\begin{array}{l}\text { Geological } \\
\text { richness }\end{array}$ \\
\hline \multirow{8}{*}{$\begin{array}{l}\text { Digital } \\
\text { elevation } \\
\text { model }\end{array}$} & $\begin{array}{l}\text { Slope map at intervals of } 0-5 ; \\
5.1-15 ; 15.1-25 ; 25.1-45 ; 45.1 \\
\text { and above degrees }\end{array}$ & $\begin{array}{c}\text { Number of typological units in } \\
\text { a studied cell }\end{array}$ & Slope richness \\
\hline & $\begin{array}{l}\text { Map of TRASP index (solar } \\
\text { radiation/aspect index); values } \\
\text { from } 0 \text { (N-NE slopes) to } 1 \\
\text { (S-SE slopes) (Evans, 2003) }\end{array}$ & $\begin{array}{l}\text { Standard deviation of index } \\
\text { values in a studied cell }\end{array}$ & $\begin{array}{l}\text { Slope orientation } \\
\text { variability }\end{array}$ \\
\hline & $\begin{array}{l}\text { Map of homogenous patches of } \\
\text { slope (same interval as Slope } \\
\text { Map) and slope orientation } \\
\text { (intervals: flat, NW, NE, SE, } \\
\text { SW) }\end{array}$ & $\begin{array}{l}\text { Number of typological units in } \\
\text { a studied cell }\end{array}$ & $\begin{array}{l}\text { Exposure } \\
\text { richness }\end{array}$ \\
\hline & & $\begin{array}{l}\text { Standard deviation of altitudes } \\
\text { in a studied cell }\end{array}$ & $\begin{array}{l}\text { Topographical } \\
\text { variability }\end{array}$ \\
\hline & $\begin{array}{l}\text { Landform map of relative } \\
\text { humidity (Topographic relative } \\
\text { moisture index - TRMI) } \\
\text { according to Manis et al. } \\
\text { (2002); } 10 \text { categories }\end{array}$ & $\begin{array}{l}\text { Number of typological units in } \\
\text { a studied cell }\end{array}$ & Relief richness \\
\hline & $\begin{array}{l}\text { Map of TRMI index rate, } 0= \\
\text { driest and } 27=\text { most humid } \\
\quad \text { (Manis et al., 2002) }\end{array}$ & $\begin{array}{l}\text { Standard deviation of index } \\
\text { rates in a studied cell }\end{array}$ & $\begin{array}{l}\text { Variability in } \\
\text { relative humidity }\end{array}$ \\
\hline & $\begin{array}{l}\text { Landform map not including } \\
\text { relative humidity(TRMI) } \\
\text { according to Manis et al. } \\
\text { (2002); } 6 \text { categories }\end{array}$ & $\begin{array}{l}\text { Number of typological units in } \\
\text { a studied cell }\end{array}$ & $\begin{array}{l}\text { Landform } \\
\text { richness }\end{array}$ \\
\hline & & $\begin{array}{l}\text { Average altitude in a studied } \\
\text { cell }\end{array}$ & Mean elevation \\
\hline \multirow{3}{*}{$\begin{array}{l}\text { Hydrographic } \\
\text { layers }\end{array}$} & & $\begin{array}{c}\text { Sum of the length of water } \\
\text { flows and the percentage of } \\
\text { water and wetland areas in a } \\
\text { studied cell }\end{array}$ & $\begin{array}{l}\text { Length and } \\
\text { proportion of } \\
\text { water/wetland }\end{array}$ \\
\hline & $\begin{array}{c}\text { Hydrographic layers converted } \\
\text { to one raster with a } 5 \mathrm{~m} \\
\text { resolution }\end{array}$ & $\begin{array}{l}\text { Percentage of water in a } \\
\text { studied cell }\end{array}$ & $\begin{array}{l}\text { Percentage/total } \\
\text { proportion of } \\
\text { water }\end{array}$ \\
\hline & & $\begin{array}{l}\text { Sum of shoreline length in a } \\
\text { studied cell }\end{array}$ & Shoreline length \\
\hline
\end{tabular}




\section{RESULTS}

As the results of the final statistical model would be less clear as an equation, the results are presented here in tabular form (Tab. 3).

Table 3: Final results of the statistical mode

\begin{tabular}{|c|c|c|}
\hline Model parameters & Křivoklátsko PLA & Šumava NP \\
\hline \multicolumn{3}{|c|}{ Significant independent variables } \\
\hline Absolute parameter & 1.3170 & 7.6239 \\
\hline Topographical variability & 0.0614 & $\mathrm{xxx}$ \\
\hline Mean elevation & $\mathrm{xxx}$ & -0.0058 \\
\hline Shoreline length & 0.0035 & 0.0013 \\
\hline Geological richness & $\mathrm{Xxx}$ & 0.2059 \\
\hline Landform richness & $\mathrm{xxx}$ & 0.1841 \\
\hline Relief richness & 0.2336 & $\mathrm{xxx}$ \\
\hline \multicolumn{3}{|c|}{ Model error (variability and correlation estimates) } \\
\hline sigma $^{2}$ & 3.0131 & 4.2983 \\
\hline Phi & 1.3883 & 1.9467 \\
\hline $\operatorname{tau}^{2}$ & 0.0000 & 0.0000 \\
\hline \multicolumn{3}{|c|}{ Criterion for model selection } \\
\hline Bayesian information criterion & 1,198 & 11,059 \\
\hline \multicolumn{3}{|c|}{ Min. rate of explained habitat richness variability } \\
\hline Regression coefficient & 0.4350 & 0.4090 \\
\hline
\end{tabular}

The model explained more than $40 \%$ of the habitat richness variability in both study areas, and it showed that heterogeneity of abiotic conditions significantly influenced habitat richness variability.

In both study areas, hydrographic heterogeneity proved to be a statistically significant variable, independently of the form in which it was formulated. According to the parameters of various statistical models, the use of shoreline length is the best means of measuring hydrographic heterogeneity and, therefore, this variable was kept in the final model. Shoreline length provides a means of representing water and wetland habitats that emphasizes ecotone biotopes.

Topographic variability and relief richness, which simultaneously provide data on the diversity of landforms and relative humidity conditions through the indirect use of features such as relief exposure and curvature, were also significant variables in the Krrivoklátsko PLA. 
Geological diversity, mean elevation (which expresses altitude gradient) and landform richness were all defined as significant variables in Šumava NP. Landform richness was used as a narrower definition of relief richness, as it evaluates only landforms (according to the slope, curvature and slope position) without reference to relative humidity.

Aside from the independent variable mean elevation, which expresses gradient and not heterogeneity, all other statistically significant variables were positively correlated with habitat richness.

\section{Model interpretation \\ Křivoklátsko PLA}

In total, 49 natural biotope types were mapped in the Krrivoklátsko PLA, whose habitat richness varied between 1 and 13 (Fig. 5).

The Krrivoklátsko PLA has been the subject of much botanical mapping. Detailed data on taxon richness for vascular plants are available for a grid square with an approximately 100 ha cell size (Kolbek et al. 2001). When this data is compared with habitat richness (using identical cell sizes), the spatial distributions of cells with highest habitat richness are almost consistent with those displaying increased taxon richness for vascular plants. The highest values occur close to the Zbirožský stream, the River Berounka and the River Klíčava (Fig. 2). The lowest values were in the northwest, where the levels of natural habitat and habitat richness were at their lowest. The taxon richness of vascular plants showed exceptionally high values in sporadic cells only. This was primarily due to the presence of the largest municipality in the region (Roztoky) and more intensive agriculture. An exception was the valley of Javornice (Fig. 2), where well-preserved forest habitats are concentrated on the hills and in the stream valley. Lower values for habitat richness and for taxon richness of vascular plants were observed southeast of the River Berounka (Fig. 2), despite the proportion of natural habitats being relatively high in the majority of these cells. This can be explained by the more monotonous site conditions (gentle downland relief and poor geological substrate), species composition (large cultural beech) and a higher altitude. According to Kolbek et al. (2001), the decrease in vascular plant richness with increasing altitude is clearly noticeable in Krrivoklátsko.

It is important that shoreline length (Fig. 5), the most significant independent variable, did not express abundance of wetland habitat alone but also habitats connected with stream and river valleys (the Zbirožský and Úpořský streams and the River Berounka). Their effects are related to the erosive activity of water, i.e. the deeply rugged relief causes high site variability through the effects of variable topoclimate, humidity conditions, temperature inversion, exposed rock substrate.

The topographical variability and relief richness variables both expressed geomorphological heterogeneity well (Fig. 6), with both showing high values in the most rugged areas.

Historical anthropogenic influences were clearly demonstrated through the use of spatial organisation of forest crops. Oak woods, which are more resistant to disturbance by grazing, forest burning or rotation period, were mainly found in areas linked with old settlements. In other areas, beech trees tended to dominate. In addition to those areas dominated by oak woods, extreme sites (insolated rock formations and scree slopes or warm southern and southeastern exposures) were also a logical exception (Svoboda, 1943). At these sites, the vast oak woods and oak-hornbeam forests, and the diversity of their subtypes, represent a unique Central European phenomenon (Kolbek at al., 1997). 
Fig. 5: Values for habitat richness and shoreline length in the Křivoklátsko Protected Landscape Area
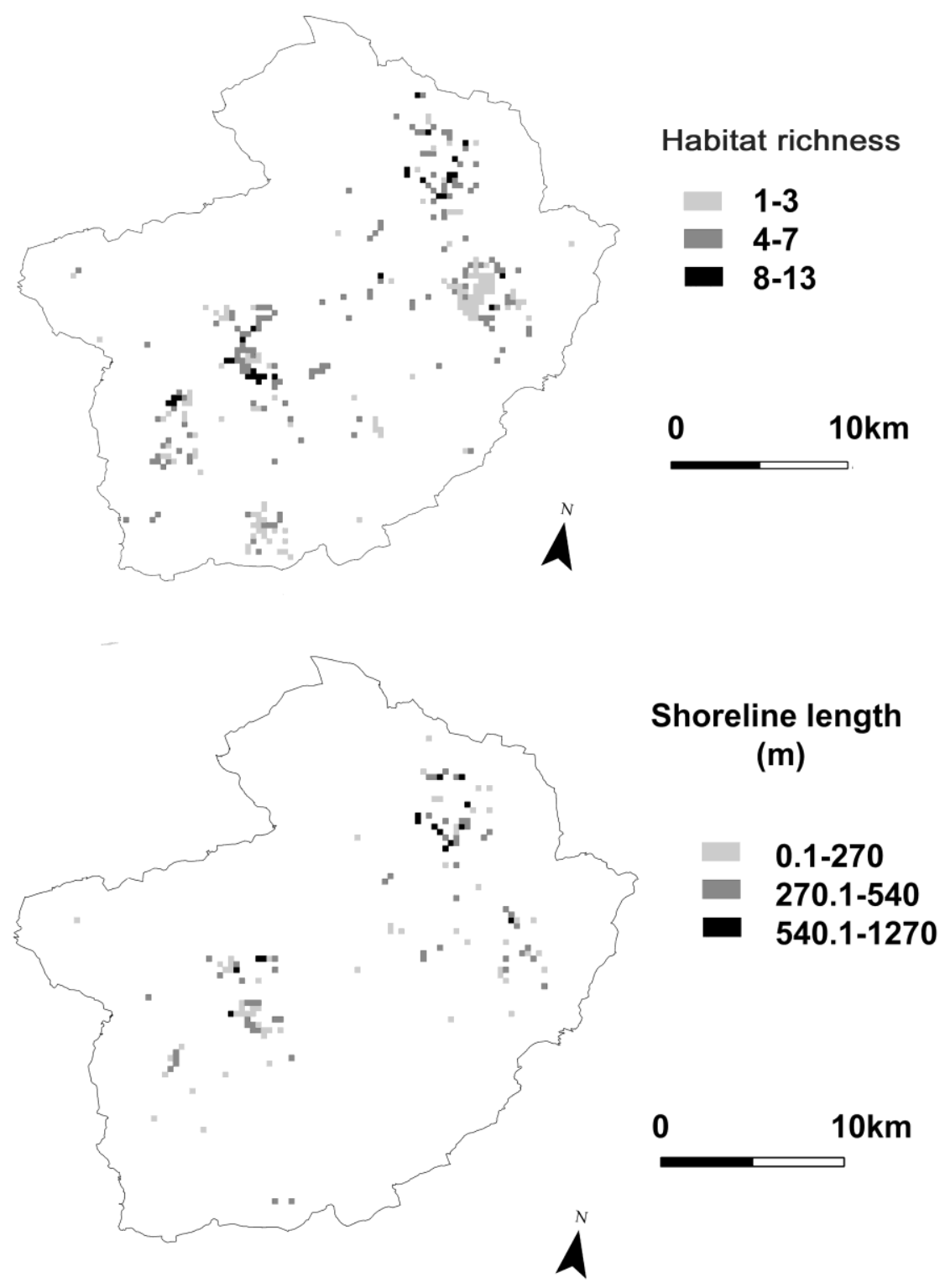
Fig. 6: Values for relief richness and topographical variability in the Křivoklátsko Protected Landscape Area
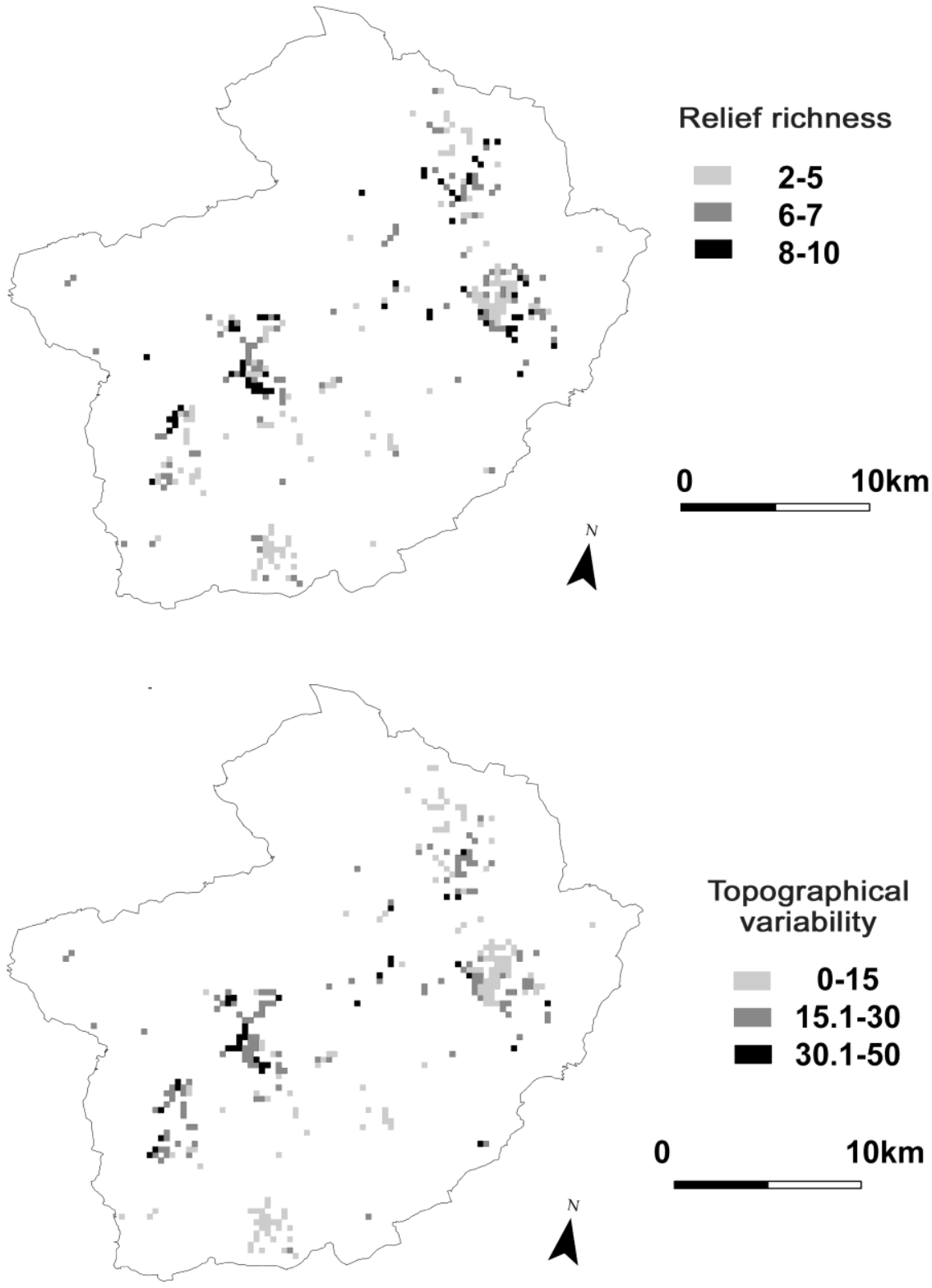

\section{Šumava NP}

The study cells were distributed unevenly over the whole area of the NP and, at the scale used, represent the best-preserved natural areas in the park. In total, 55 separate types of natural habitat were registered. The values for habitat richness varied from 1 to 18 habitat 
types (Fig. 7). The majority of study cells, however, showed low values (a result of more homogenous natural conditions and a cell size that was more suitable for the Krrivoklátsko PLA study area). The connections between high values for habitat richness and those for the network of water flows and specific wetland conditions (large abundance of mosses and waterlogged locations) were striking. This relationship was expressed using the shoreline length variable and, to a greater degree, also by geological diversity (Fig. 8), which indicated substrate enrichment of moorland sediments and, at a local level, also of fluvial sediments. The Hornovltavský floodplain (Fig. 3) represents a unique locality with exceptionally high habitat richness and is one of the best-preserved river systems in the Czech Republic. The floodplain hosts a wide range of habitats linked with both streamless and flowing waters, as well as a wide range of humid meadows and moorland vegetation associations, with a predominance of grass-herb vegetation.

\section{Fig. 7: Values for habitat richness in Šumava National Park.}

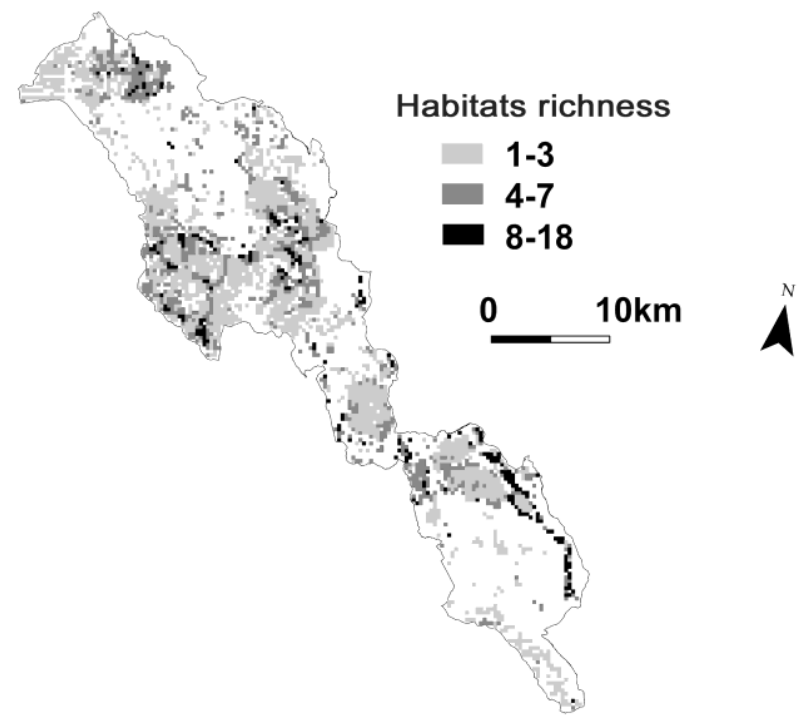

Most of the study cells with high values for habitat richness were connected with various wetland habitats. Of these, the deep valley with numerous scree slope accumulations on the lower stretch of the River Vydra (Fig. 3) could be clearly distinguished. At this site, rock and scree habitats have their greatest extent and habitat richness is increased further by a covering of scree woodland. Only at the rocky enclaves surrounded with beech wood and in Stožecko (Fig. 3) is there another location with a higher ratio of scree woodland in Šumava NP.

A noticeable decrease in habitat richness typifies a shift to coherent zonal forest units (beech woodland and mountain spruce forests), as seen, for example, with the low values for the Plešská upland and east of the River Vydra. This trend was expressed using the mean elevation variable (Fig. 8). Spruce forest habitats dominated, along with non-natural cultural spruce forest habitat, in the south of the Plešská upland (Trojmezná peak). Locally increased values in habitat richness were related to territorial enrichment by the rare 
quillwort association at Plešné Lake and by an alpine non-forested area at the edge of Plechý peak. At the southern tip of the national park, the forest cover shifts from pine woods into vast beech woods.

Šumava NP is typified by a gently rugged relief that is locally enriched with distinct landforms. The diversification of habitat composition in such locally enriched areas (e.g. on the upper stretch of the River Křemelná) was expressed using the landform diversity variable (Fig. 8).

Fig. 8: Values for landform richness, shoreline length, mean elevation and geological richness in Šumava National Park
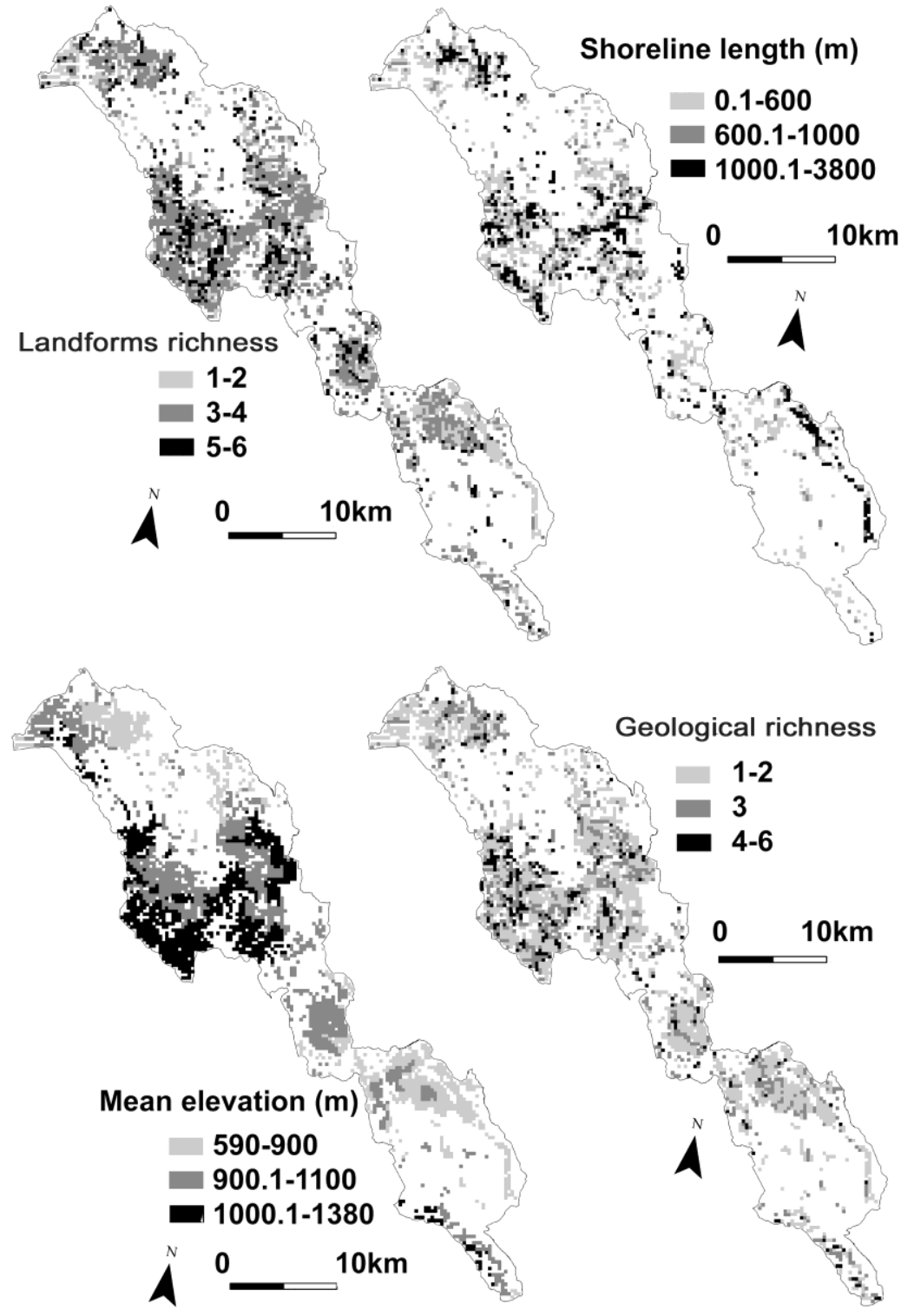


\section{DISCUSSION}

Our initial hypothesis, that habitat richness would be high in areas with high abiotic heterogeneity, was confirmed. Some methodological deficiencies, however, still remain. Most of the imperfections in the model result from the character of the input data used for habitat richness assessment. The unique spatial extent of NATURA 2000 mapping requires an enormous number of fieldworkers, whose levels of knowledge and ability vary. A certain level of inaccuracy or subjectiveness for the set parameters will, therefore, find its way into the final data set. This data set remains, however, the most relevant source covering all the territories of our valuable natural areas. Further, the habitat types used in the NATURA 2000 system tend to be defined using different methods, i.e. though the majority of habitat types have been described using the abundance of diagnostic species of plants, some habitats are defined using abiotic factors. In these few cases, therefore, data circularity occurs when the relationship between geodiversity and habitat richness is assessed. A further methodical problem arises with the perception of landscapes as a planimetric surface when constructing the grid square. This leads to an inequality in the true sizes of areas within cells.

Despite the aforementioned inaccuracies, the model developed in this study provides a new point of view for the study of these areas and for landscape evaluation generally. The model can serve as a base for further research. Such research, however, should always consider the above points when interpreting the results.

\section{CONCLUSION}

Šumava NP and the Krrivoklátsko PLA are among the best-preserved natural areas in the Czech Republic. Our initial hypothesis, that habitat richness would be high in areas with high abiotic heterogeneity, was confirmed with a relatively high positive correlation. The statistical model explained more than $40 \%$ of habitat richness variability at both study areas. In the Krrivoklátsko PLA, topographic variability, relief richness and shoreline length represented significant variables for abiotic heterogeneity. In Šumava NP, mean elevation, landform richness, geological richness and shoreline length were the most significant variables. Natural conditions in Šumava NP were more monotonous than those in the Krrivoklátsko PLA, the PLA being characterised by a diverse geological substrate and topography and Šumava NP having a characteristically gentle relief and poor geological substrate. Specific wetland conditions and, even more so, mountain climates that are modified by topography, have local effects in rich habitat mosaics, as seen in various parts of the Krrivoklátsko PLA.

This paper provides a contribution not only through the results achieved but also through the quantitative methodological procedure developed (GIS, spatial statistics), which also provides a basis for the assessment of geodiversity. Some methodological gaps remain, however, and it is necessary to consider these when interpretating results.

Although every model represents a simplification of reality, and natural conditions present multi-dimensional areas with high rates of inexplicable variation (Kučera, 1997), the development of quantitative methods of landscape evaluation provides for a deeper understanding of the processes involved, as well as for appropriate landscape management measures in the future. Quantitative methodologies and the use of GIS, therefore, should form the backbone of any terrain mapping exercise, and it is likely that, due to their 
potential, they will increasingly be used in both landscape ecology studies and in the field of landscape protection.

\section{ACKNOWLEDGMENTS}

This paper was produced with the support of the research project "KJB601110701 Evaluation of the landscape diversity and heterogeneity changes according to the system of landscape indicators".

\section{REFERENCES}

Administration of Šumava NP (2007). Administration of Šumava NP. Retrieved 2007, February, from http://www.npsumava.cz/

Agency of nature conservation and landscape protection of the CR (2006). Vector layer of habitats for the areas of Šumava NP and Křrivoklátsko PLA.

Anonymous (2002). Australian Natural Heritage Charter. Australian Heritage Commission, Canberra, p 32.

Beyer, H. L. (2004). Hawth's Analysis Tools for ArcGis. Retrieved 27.2.2007, from http://www.spatialecology.com/htools/index.php

Burnett, M.R., August, P.V. \& Brown, J.H. (1998). The influence of Geomorphological Heterogeneity on Biodiversity I. A Patch-Scale Perspective. Conservation Biology, 12 (2): 363-370

CZech Geological Service (2006). Geological map from the GEOCKR 50 database for the areas of Šumava NP and Křivoklátsko PLA.

Cílek, V. (2002). Geodiverzita. Ochrana přirody, 57 (2): 40-44

Chytrý, M., Kučera, T. \& Kočí, M. (2001). Habitat catalogue of the Czech Republic. ANCLP CR, Prague, pp 307.

COSMC (Czech office for surveying, mapping and cadastre) (2006). Digital terrain model and hydrographical layers from ZABAGED database for the areas of Šumava NP and Krivoklátsko PLA.

Costanza, R., Fisher, B., Mulder, K., Liu, S. \& Christopher, T. (2007). A multi-scale empirical study of the relationship between species richness and net primary production. Ecological Economics, 61: $478-491$.

Davidar, P., Mohandass, D., Puyravaud, J., Condit, R., Wright, S.J. \& Leigh, E.G. (2007). The effect of climatic gradients, topographic variation and species traits on the beta diversity of rain forest trees. Global Ecology and Biogeography, 16 (4): 510 - 518.

ESRI (2006). ArcGIS 9.2. \& ArcInfo workstation 9.2. Environmental Systems Research Institute, Inc.

Evans, J. (2003). Topographic Radiation Index. Retrieved 10.7.2007, from http://arcscripts.esri.com/ details.asp?dbid=12643

Free Software Foundation (2007). Free Software Foundation-R 2.5.0. Free Software Foundation, Inc.

Gordon, J.E., Morrocco, S., Ballanyne, C.K. \& Thompson, B.A. (2006). Links between geodiversity and biodiversity on upland plateaux in Scotland: the importance of terrain sensitivity in managing change. Retrieved 28.6.2007, from http://www.cms.uhi.ac.uk/ conferences/upland_biodiversity _Dec2006/Gordon_extendedabstract.pdf

Gustafson, E.J. (1998). Quantifying landscape spatial pattern: what is the state of the art? Ecosystems, 1 (2): 143 - 156

Guth, J. (2002). Metodiky mapováni biotopi̊ soustavy Natura 2000 a Smaragd. ANCLP CR, Prague, pp 35.

Gray, M. (2004). Geodiversity - valuing and conserving abiotic nature. John Wiley \& Sons Ltd, Chichester, pp 434. 
Jačková, K. (2007). Hodnocení vlivu diverzity abiotických podmínek na diverzitu biotopů v NP Šumava a CHKO Křivoklátsko. Diploma thesis, Department of the physical geography and geoecology, Faculty of Science, Charles University in Prague, pp 76.

Kolbek, J., Blažková, D., Husová, M., Moravec, J., Neuhauslová, Z. \& Sádlo, J. (1997). Potenciálni přirozená vegetace biosférické rezervace Křivoklátsko. Academia, Prague, pp 234.

Kolbek, J., Brabec, E., Hroudová, Z., Vítková, Z. \& Kučera, T. (2001). Květena CHKO a BR Křivoklátsko, 2.Rozbor a syntéza. Botanický ústav AV ČR, Prague, pp 132.

Kot, R. (2006). Ocena georóznorodnosci klimatu na przyktadzie fordonskiego odcinka doliny dolnej Wisty $i$ jej otoczenia w skali 1:25000. Retrieved 19.7.2007, from http://www.paek.ukw. edu.pl/ wydaw/vol17/vol_17.htm

Kozlowski, S. (2004). Geodiversity. The concept and scope of geodiversity. Przeglad Geologiczny, $52(8 / 2): 833-837$.

Kučera, T. (1997). Vliv reliéfu na diversitu vegetace. Disertační práce na katedře botaniky PřF UK v Praze, pp 128.

Kučera, T. (1999). Ekologické fenomény a biodiverzita. Živa, 152 (3): 111 - 113.

Ložek, V.(2000). Biodiverzita, ekofenomény a geodiverzita. Vesmír, 79 (2): 77 - 83.

Ložek, V. (2005). Biodiverzita a geodiverzita. Ochrana př́rody, 60 (7): 195 - 199.

Manis, G., Lowry, J. \& Ramsey, R.D. (2002). Pre-classification: An Ecologically Predictive Landform Model. Retrieved 10.4.2007, from http://earth.gis.usu.edu/swgap/ landform.html\# landform_aml.

Nichols, W.F., Killingbeck, K.T. \& August, P.V. (1998). The Influence of Geomorphological Heterogeneity on Biodiversity II. A Landscape Perspective. Conservation Biology, 12 (2): 371 - 379.

Pebesma, E.J., Bivand, R. (2007). A package sp: classes and methods for spatial data. Retrieved 10.5.2007, from http://cran.biokontakt.cz/src/contrib/Descriptions/sp.html

Pemberton, M. (2002). Conserving geodiversity, the importance of valuing our geological heritage. Retrieved 1.7.2007, from http://www.dpiw.tas.gov.au/inter.nsf/Attachments/SJON-57W5Z5/ \$FILE/geocon_abstract.pdf.

Prosser, C. (2002). Terminology: speaking the same language. Earth heritage, 18: 24 - 25.

Ribeiro, Jr. P.J. Diggle P.J. (2007). geoR: A package for geostatistical analysis. Retrieved 11.4.2007, from http://cran.biokontakt.cz/src/contrib/Descriptions/geoR.html

Sharples, C. (2002). Concepts and Principles of Geoconservation. Tasmanian Parks \& Wildlife Service website. Retrieved 3.1.2007, from http://www.dpiw.tas.gov.au/inter.nsf/ Attachments/ SJON57W3YM/\$FILE/geoconservation.pdf

Silva, J.X. (2004). Geodiversity: Some Simple Geoprocessing Indicators to Support Environmental Biodiversity Studies. Retrieved 9.1.2007, from http://www.directionsmag.com/ article.php?article $\mathrm{id}=473 \& \operatorname{trv}=1$.

Spehn, E., Körner, K. (2003). Global mountain biodiversity assessment: A diversitas network. In: Status and trends of, and threats to, mountain biodiversity, marine, coastal and inland water ecosystems: Abstracts of poster presentations at the eighth meeting of the Subsidiary Body on Scientific, Technical and Technological Advice of the Convention on Biological Diversity. pp 34-36. Secretariat of the Convention on Biological Diversity, Montreal. Retrieved 2007, February, from http://www.cbd.int/doc/publications/cbd-ts-08.pdf

Stanley, M. (2003). Geodiversity: Our foundation. Geology Today, 19 (3): 104 - 107.

The Math Works (2006). Matlab R2006a. The Math Works Inc. 